\title{
A KEY TO THE SPECIES OF WISCONSIN ANTS, WITH NOTES ON THEIR HABITS.
}

\author{
A. C. Burrill and M. R. Smith.
}

The writers are particularly indebted to Dr. W. M. Wheeler, of Harvard University, for the identifications of a number of * the species here given and for the frequent references to his notes.

We are also highly indebted to the gentlemen, whose names are mentioned below, for acknowledged assistance given in the preparation of this paper.

Mr. C. E. Brown, Curator of the Museum of the University of Wisconsin, for a list of his collections in the State of Wisconsin and for notes in connection therewith.

Mr. T. E. B. Pope, Curator of the Milwaukee City Museum for furnishing the authors with a list of the Wisconsin species in the Museum.

Mr. F. H. Gaige, Curator of the University of Michigan Museum, for furnishing the writers with several species for study.

Mr. H. F. Wilson, Entomologist of the University of Wisconsin, for the identifications of aphids, which were being attended by the ants.

Mr. H. S. Barber, U. S. Bureau of Entomology, for the identification of Coleopterous larvæ.

\section{Subfamily FORMICIDE.}

1. Abdominal pedicel consisting of a single segment $\ldots \ldots \ldots \ldots \ldots \ldots \ldots \ldots 2$.

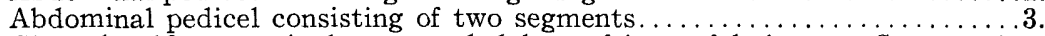

2. Cloacal orifice terminal, surrounded by a fringe of hairs..... Camponotince.

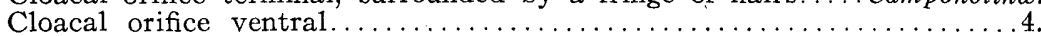

3. Frontal carinæ very close together, almost vertical, not covering antennal insertions; eyes small or absent...................... Dorylina.

Frontal carinæ not as above; eyes rarely vestigial or absent.......Myrmicina.

4. No constrictions between the first and second gastric segments; anal glands present, which produce a secretion with a rancid butterlike odor...

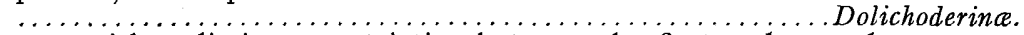

Gaster with a distinct constriction between the first and second segments; frontal carinæ separated or close together............... Ponerince. 


\section{Subfamily CAMPONOTINÆ.}

1. Antennæ with nine joints....................... Brachymyrmex Mayr.

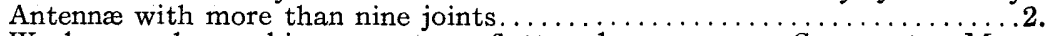

2. Workers polymorphic, pronotum flattened.................................... Workers not polymorphic, though of variable size...................

3. Large robust ants with three prominent ocellar spots on vertex of the head,

........... Formica Linn.

Smaller, more slender ants with less prominent ocellar spots on vertex of

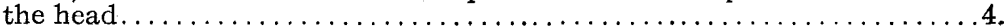

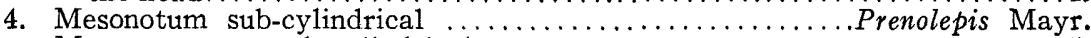
Mesonotum not sub-cylindrical ...........................

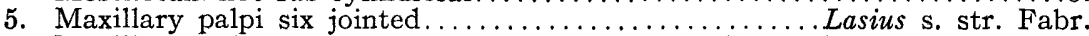
Maxillary palpi three jointed....................................

\section{Genus Brachymyrmex Mayr.}

B. heeri depilis Emery.

A small, pale yellowish species with nine jointed antennæ. It is the smallest of the Wisconsin ants recorded in this paper.

The workers build their nests under stones in shady woods and attend root Coccids and Aphids.

\section{Subfamily Camponotrnæ. \\ Genus Camponotus Mayr.}

1. Clypeus with a notch in the middle of its anterior border.

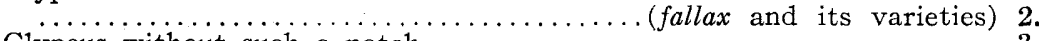

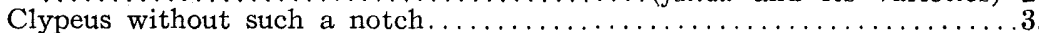

2. Form slender; head, thorax and abdomen smooth shining black, practically devoid of hairs except for the fringe of hairs on the posterior edge of each segment of the abdomen.............fallax var. nearcticus Emery.

3. Color black; head and thorax sparsely covered with large yellow hairs; the abdomen with numerous large hairs and rather pubescent giving it a bronzed appearance.....................herculaneus pennsylvanicus De Geer.

Color yellow and black or red and black. .......................

4. Yellow or brownish red in color, gaster dark, head much darker than either,

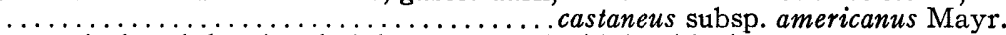

5. Thorax dark red, head and abdomen smooth shining black............ .......................herculaneus ligniperda var. noveboracensis Fitch.

Thorax black, mottled with red, the latter color being confined to the posterior part of the thorax...........herculaneus var. whymperi Forel.

C. herculaneus subsp. pennsylvanicus De Geer.

This ant is the most widely distributed species of the genus, ranging from southern Canada over the North Atlantic and Middle Western States as far west as Texas and South Dakota; for this reason it has been more often noticed than the other members of this group.

Nests are built in logs, stumps or the dead wood of standing trees; occasionally they nest in houses where they may do considerable damage by tunneling in the wood. 
C. herculaneus ligniperda var. noveboracensis Fitch.

The workers of this beautiful form have a black head and gaster and a dark red thorax. The body surface is rather smooth and shining.

This species ranges across the continent from the Atlantic to the Pacific, between Nova Scotia, its northern-most limit and Maryland, its southern-most limit. In the Atlantic States it nests at high elevations. It is a wood nesting species also.

Workers have been found attending Thelia bimaculata on locust at Madison, Wisconsin.

Staphylinids found occurring in their nests were identified by Dr. A. Fenyes, of Pasadena, California, as Anomognathus cuspidatus Fabr.

\section{C. castaneus var. americanus Mayr.}

These ants are very variable in coloration. The Wisconsin specimens before the writer are reddish brown, with a black head.

Nets which are built under stones in the woods, contain, numerous individuals.

C. americanus ranges over the Atlantic States and as far west as Texas and Illinois.

\section{C. herculaneus var. whymperi Forel.}

This form is somewhat variable in coloration, with portions of the body either red or black. The specimens examined were black with the exception of the posterior portion of the thorax, legs and petiole, which are light yellowish red.

C. whymperi.nests at high elevations usually; when found in the lowlands, it occurs in cold tamarack bogs, or the cold woods of the Alleghanies, etc. For the reasons given, it appears to be a Boreal or Alpine form. Their nests, consisting of large colonies, are built in logs and stumps.

\section{C. fallax var. nearcticus Emery.}

These ants are much more smaller and slender than are those just mentioned. They are smooth, shining black.

Nests consisting of a few individuals are found under the bark of trees. 


\section{Genus Lasius Fabr.}

1. Maxillary palpi with six joints...................... Lasius $\mathrm{s}$. str. 2 . Maxillary palpi with three joints.................. subgen. Acanthomyops 4.

2. Scapes and legs with erect hairs................niger var. neoniger Emery. Scapes and legs without erect hairs.................................

3. Body brown in color......................niger var. americanus Emery. Body yellow in color; hairs on the abdomen subdepressed.....

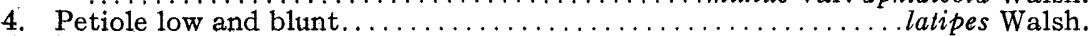

Petiole higher and thinner. . . . . . . . . . . . . . .

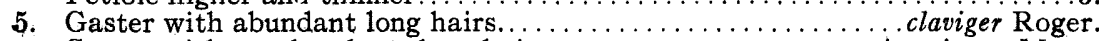

Gaster without abundant, long hairs............... interjectus Mayr.

\section{L. niger var. americanus Emery.}

This species is the most abundant of all our North American ants, occurring throughout the country except in the extreme southern and southwestern section. It shows great adaptability in its nesting habits and may be found in the damp rotten wood of forests or in the gravelly soils of open fields. In the open fields their nests consist of small craters.

The workers are exceedingly fond of the sweet secretions of aphids or other honey dew secreting insects and may often be found in attendance upon such forms. Their relation to the corn and cotton root louse, Aphis maid radicis, has caused this species to be considered of great economic importance. Dr. Forbes, of Illinois, has published some very interesting reports on the habits and life economy of this species.

Workers of Lasius americanus have been collected that were heavily infested with a parasitic fungus known as Laboulbenia formicarium Thaxter.

\section{L. niger var. neoniger Emery.}

This ant may easily be mistaken for L. americanus from which it differs by the presence of erect hairs on the antennal scapes and legs.

The habits of the two species are the same.

Workers have been observed attending $A$. forbesii on strawberry plants.

L. umbratus mixtus var. aphidicola Walsh.

This is a rather robust, yellowish brown species with subdepressed hairs on the gaster.

Nests are constructed under stones or in the base of stumps in damp shady woods. The colonies are rather large and are given to cultivating subterranean aphids. 


\section{Subgenus Acanthomyops Mayr.}

L. (A.) interjectus Mayr.

The workers of this species are yellow and robust, with an agreeable body odor somewhat similar to that of lemon verbena. This is the largest species of the genus.

Nests are built under stones, in logs or in stumps. The workers which are very numerous in the colonies attend aphids underground.

\section{L. (A.) claviger Roger.}

This species is smaller than $L$. interjectus and possesses abundant long hairs on the gaster. The lemon verbena like odor is also present about the workers.

L. claviger is the most abundant species of the subgenus Acanthomyops. It nests under stones.

L. (A.) latipes Walsh.

Females of this form are dimorphic. One of the forms being very hairy and possessing much flattened femora and tibiæ.

Nests are constructed under stones.

\section{Genus Prenolepis Mayr.}

\section{P. imparis Say.}

This species is the largest ant of the genus, measuring from $3-4 \mathrm{~mm}$. in length. It is also the most widely distributed, ranging from the Atlantic to the Pacific in the Transition Zone. The typical form is dark brown, while the variety is much smaller and paler.

The workers are exceedingly fond of sweets, aphid excretions, etc., and are very commonly found attending aphids, coccids, and membracids. When the workers are full of honey dew, their abdomens are very much distended; this when they are walking gives them the appearance of swaggering like a drunken man.

This species has been observed to be much of a house pest in the South Atlantic States.

Their nests, which are located in moist clay like soils, are small craters made of irregular pellets, which resemble the pellets of the ants of the subgenus Trachymyrmex. A colony consists of from 300 to 400 individuals. The males and females pass the winter in the colony nest and take their nuptial flights early in the spring. 


\section{Subgenera and Groups of the Genus Formica Linn.}

1. First funicular joint about as long as the second and third taken together.

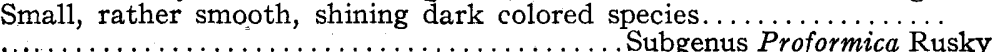
irst funicular joint shorter than the second and third taken together....

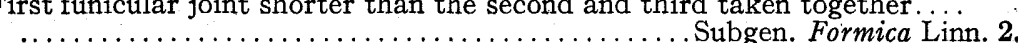

2. Anterior edge of clypeus notched or emarginate in the middle..sanguinea group. Anterior edge of clypeus entire, rounded or subangularly produced in the

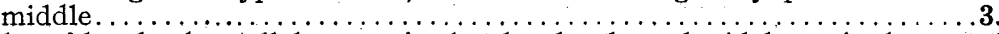

3. Sides of head subparalle1, posterior border deeply and widely excised....

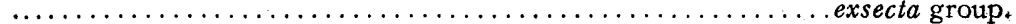

Sides of head converging anteriorly, posterior border straight, convex or

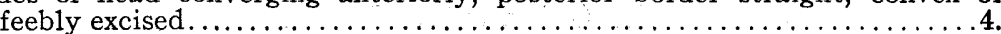

4. Body robust. Head of largest individuals not or hardly longer than broad. Body opaque, color light or dark red with black gaster. .......rufa group.

Body more slender. Head of largest individuals longer than broad. Petiole narrow, rather thick and with a blunt border. Color and sculpture

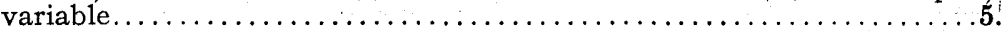

5. Thorax rather short. Scapes distinctly curved at the base. Petiole flattened behind.....................................fusca group.

Thorax longer. Scapes slender, very slightly curved at the base. Petiole

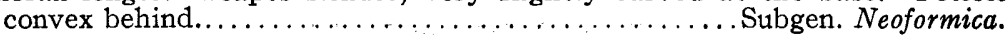

\section{Subgenus Proformica Rusky.}

F. (P.) neogagates neogagates Emery.

A small, smooth, dark or black shining species with light reddish colored mandibles, antennæ and legs. Sometimes the cheeks and clypeus are light red in color.

The workers of this species resemble the small workers of $F$. subpolita and for this reason the two species are sometimes confused. $F$. neogagates differs from the former in its more abundant, more finer and paler pilosity.

The ants nest in small colonies under stones and are very. timid. They are a Sub-Boreal species and are not often found at low elevations.

$F$. sanguinea and its various subspecies make slaves of this species.

\section{Subgenus Formica Linn.}

\section{Sanguinea Group.}

1. Head long and narrow. Color of head, thorax and petiole brownish testaceous.

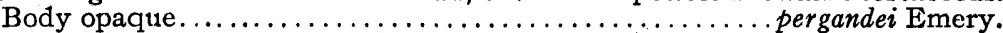

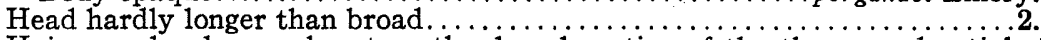

2. Hairs nearly always absent on the dorsal portion of the thorax and petiolar border; short and sparse on the head and gaster. . sanguinea subnuda Emery.

Hairs present on the dorsal portion of the thorax and petiolar border; longer

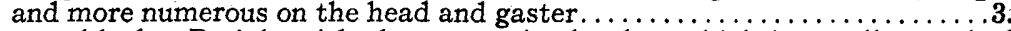

3. Gaster black. Petiole with sharp superior border, which is usually notched in the middle.......................... sanguinea rubicunda Emery.

Gaster brown. Petiole with blunt superior border, which is usually entire. $\ldots \ldots \ldots \ldots \ldots \ldots \ldots \ldots \ldots \ldots \ldots \ldots \ldots \ldots \ldots \ldots \ldots \ldots \ldots \ldots \ldots$ sanguinea subintegra Emery. 
F. pergandei Emery.

The writers have not seen specimens of this species, although it is known to occur in Wisconsin. Wheeler states that this species is rare.

F. sanguinea subnuda Emery.

This species is a Boreal or Alpine form and is not very easily distinguished from $F$. aserva.

It makes slaves of $F$. fusca vars. subsericea, argentea, subaenescens, and gelida.

\section{F. sanguinea rubicunda Emery.}

Workers of this subspecies vary in color and character of pilosity. This subspecies is not as abundant as the subspecies subintegra and subnuda. slaves.

F. subsericea, neogagates, schufussi and neocinerea are its

\section{F. sanguinea subintegra Emery.}

F. subintegra may be distinguished from rubicunda by the smaller size, peculiar color of the gaster and the narrower blunter petiole of the worker.

It is the common form of sanguinea in the Eastern States and Canada at low elevations in warmer situations.

The following species are made slaves of by $F$. subintegra, $F$. fusca and vars. subsericea, subaenescens, $F$. cinerea neocinerea, neogagates, vidua; $F$. pallide-fulva schaufussi, nitidiventris, fuscata and incerta.

\section{Exsecta Group.}

1. Posterior portion of the head black....................ulkei Emery.

Posterior portion of the head not black.....exsectoides exsectoides Forel.

\section{F. ulkei Emery.}

Wheeler states that this species is peculiar to the Canadian fauna but is very rare in the Transition Zone.

The nests are flattened mounds a foot or more in diameter, composed of earth and vegetable matter.

A larva of Coscinoptera dominicana Fabr. was found in the nest of this species.

\section{F. exsectoides exsectoides Forel.}

$F$. exsectoides is the famous mound building ant of the Alleghany Mountains, of whose interesting habits Rev. H. C. 
McCook has made a thorough study. The nests are conical mound from two to ten feet in convex diameter, consisting principally of earth. They are located in open places in the woods.

The workers are very ferocious and will attack anyone trespassing on their domains. They kill other ants by decapitation.

This species is a temporary parasite of $F$. fusca var. subsericea.

Rufa Group.

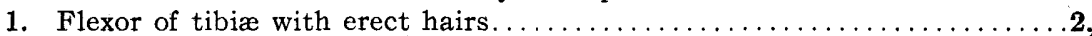

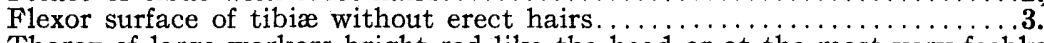

2. Thorax of large workers bright red like the head or at the most very feebly infuscated...............................rufa aggerans Wheeler.

Thorax of small workers deeply infuscated. Pubescence on the gaster weaker. $\ldots \ldots \ldots \ldots \ldots \ldots \ldots \ldots \ldots \ldots \ldots$.........................

3. Head and thorax of small workers spotted with brown. Frontal area shining,

Head and thorax of small workers generally without fufa obscuripes Forel spotted, the spots are pale. Frontal area slightly brown spots; when

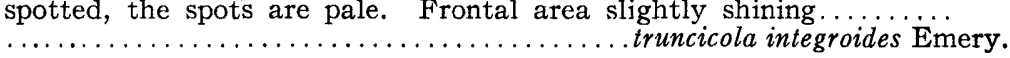

\section{F. rufa aggerans Wheeler.}

This robust species is the common thatching ant of the Western States. Their nests are small, more or less flattened mounds covered with coarse straws, sticks or vegetable matter.

The Junior writer has observed this species attending Pubilia concava on Helianthus sp.? and Thelia bimaculata on locust.

F. rufa aggerans var. melanotica Wheeler.

This variety possesses the same nesting habits as the species just mentioned except that their nests are smaller, being from a foot to a foot and a half in diameter and are constructed in grassy fields.

The Senior author has observed this species having its nest covered with the larvæ of Coscinoptera dominicana Fabr.

\section{F. rufa obscuripes Forel.}

Wheeler states that this form is imperfectly known. The absence of erect hairs on the tibiæ of the legs is not a very strong character for separating this species from other members of the group.

Nests of this ant are similar to those of $F$. aggerans.

The species is peculiar to the Northwestern States, occurring at elevations between $5,000-8,000$ feet. 
F. truncicola integroides Emery.

The workers of this species pile large quantities of vegetable debris about stumps and logs and make their nests in the stumps and bogs.

The writers have not seen specimens of this ant from Wisconsin.

Fusca Group.

1. Gula with erect hairs. Top of head much darker than the other portions of the head....................inerea cinerea var. neocinerea. Wheeler. Gula without erect hairs. Pubescence on the gaster dense and silky.....

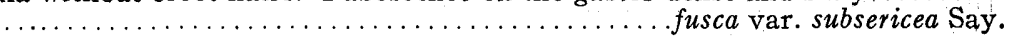

\section{F. cinerea cinerea var. neocinerea Whlr.}

The workers build flattened mounds in the meadows and bogs of the Northwestern States.

The Junior writer has observed this species attending Pubilia concava on Helianthus sp. It has been observed by the Senior writer to attend $A$. pomi on apple.

\section{F. fusca var. subsericea Say.}

This beautiful shining species is one of the most abundant ants in North America. It is very widely distributed throughout the Eastern States.

The workers are cowardly ants and are made slaves of by ants of the groups sanguinea, rufa and exsecta. Although they feed on insects to a large extent, the workers are also given to attending aphids.

Nests are built under stones or in low flat mounds in sunny places. Their nests often disfigure beautiful lawns in the Northern States.

$F$. subsericea has been observed to attend the following aphids: Chaitophorus populicola on poplar, $C$. negundinis on box elder, C. nigrae on Salix fragilis and the membracid, Pubilia concava on Helianthus sp.

\section{Subgenus Neoformica.}

1. Erect hairs present on the gula and petiole ........................

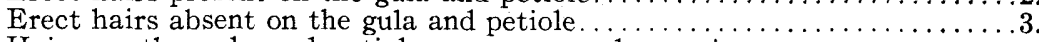

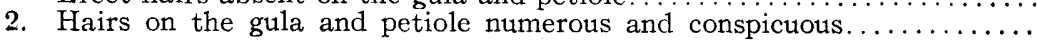

pallide-fulva schaufussi Mayr.

Hairs on the gula and petiole few, often lacking on one or the other; head thorax and gaster darker.....pallide-fulva schaufussi var. incerta Mayr.

3. Head and thorax brown or reddish brown, gaster shining. pallide-fulva nitidiventris Emery.

Head and thorax darker, body often less shining ................ ....................... pallide-fulva nitidiventris var. fuscata Emery. 
F. (N.) pallide-fulva schaufussi Mayr.

A very common form throughout the Northeastern States. Their colonies, which are fairly large, consist of nests under stones or in craters in open sunny fields, pastures, etc.

The workers are very timid. They feed on dead insects and the excretions of aphids.

F. (N.) pallide-fulva schaufussi var. incerta Emery.

This variety has habits similar to those of $F$. schaufussi, but ranges farther west than that species. There is a considerable variation in the individuals from different colonies or localities and it is not always easy to separate this species from the species nitidiventris or schaufussi.

F. (N.) pallide-fulva nitidiventris Emery.

This species has a range that nearly coincides with that of incerta. The habits of $F$. nitidiventris are similar to those of the species just discussed.

F. (N.) pallide-fulva nitidiventris var. fuscata Emery.

The workers are much darker than those of $F$. nitidiventris. The habits of the two, are however, practically the same,

\section{Subfamily Myrmicince.}

1. Postpetiole joined to the dorsal surface of the gaster...Cremastogaster Lund. Postpetiole not joined to the dorsal surface of the gasterr..............

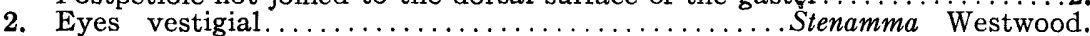

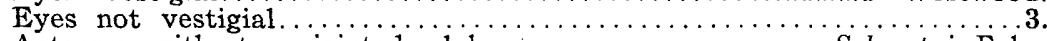

3. Antennæ with two jointed club............................

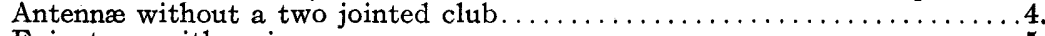

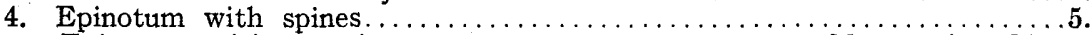

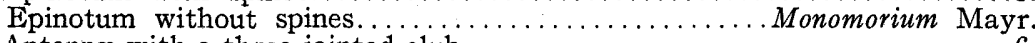

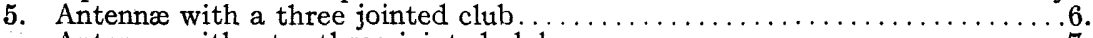

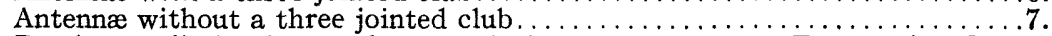

6. Prothorax distinctly angular anteriorly ................. Prothorax not angular anteriorly; small ants that nest in galls, nuts, etc..

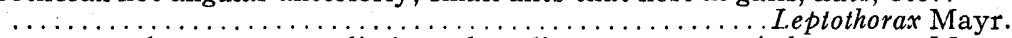

7. Promesonotal suture very distinct dorsally..............Aphanogaster Mayr.

Promesonotal suture not very distinct dorsally; head and thorax coarsely rugose reticulate................................

\section{Genus Cremastogaster Lund.}

\section{C. lineolata Say.}

This species ranges over the whole of North America from the Atlantic to the Pacific to an altitude of about 7,000 feet in the Rocky Mountains. There are a number of varieties and subspecies of this form. 
The workers are very fond of aphid excretions and like substances and for this reason are commonly found in attendance upon honey dew secreting Hemipterans.

Their nests may be found in the soil under rocks, in dead wood, or under the bark of trees. The nests have a very peculiar rank odor.

The workers when in large numbers are rather courageous and will sting or bite. They have a peculiar habit of carrying their gasters pointing upward, which much resembles the habits of Staphylinids.

\section{Genus Leptothorax Mayr.}

L. acervorum subsp. canadensis Provancher.

A small brownish species with dark gaster, having the thorax faintly, but distinctly impressed at the mesoepinotal suture.

Wheeler states that it is a rather rare boreal form, which nests under bark in small colonies.

\section{Genus Tetramorium Mayr.}

T. guineese Fabr.

This species is reddish yellow with the exception of the gaster which is almost black. The carinal grooves extend to within a short distance of the posterior corners of the head.

Workers were collected in a greenhouse at Milwaukee, Wisconsin. Their habits are similar to those of T. caespitum.

\section{Genus Solenopsis Westwood.}

S. molesta Say.

The minute workers of this species are yellow and have distinct two jointed antennal clubs.

This ant is very common to the Northern and Eastern States. In Kansas it is known to attack corn and related cereal crops. The workers gnaw into the kernels of the grain and destroy the germinating portions, thus seriously damaging the crop. Occasionally this species attacks small fruits, like strawberries and raspberries and injures the fruit by eating out irregular holes. 


\section{Genus Monomorium Mayr.}

1. General body color shining black................ minimum Buckley. General body color yellowish with gaster slightly infuscated. pharaonis Linn.

\section{M. minimum Buckley.}

The small shining black workers of this species make small crater-like nests in sandy or gravelly soil. The writers have also found them nesting in rotten wood.

Workers are frequently observed crawling over flowers, where they are in search of the extra floral nectaries.

\section{M. pharaonis Linn.}

This little yellow or red house ant is an imported species, which has become quite common in houses, where it feeds on sweets, breads, meats, etc. The writer has seen several flats vacated because of the ravages of this pest.

\section{Genus Aphaenogaster Mayr.}

1. Epinotal spines as long as the base of the epinotum, or longer; color red.

............................tennesseensis Mayr.

Epinotal spines not as above; shorter than one-half the base of the epinotum. 2.

2. Color reddish brown......................... fulva subsp. aquia Emery.

Color pitchy black........................ fulva aquia var. picea Emery.

\section{A. tennesseensis Mayr.}

The beautiful workers of this form occur in the Northeastern States, where they live in mixed colonies with $A$. fulva and its. varieties. Their nests are usually found in rotten wood.

This species bears a close resemblance to $A$. lamellidens and has been mistaken for it. A. lamellidens, however, does not occur as far north as this species.

\section{A. fulva subsp. aquia Emery.}

A slender brown species that nests under stones in the woods. The workers feed on dead insects.

\section{A. fulva aquia var. picea Emery.}

A darker variety of the subspecies. The habits of this and the former are the same. 


\section{Genus Myrmica Latr.*}

1. Antennal scape with a tooth or transverse lamina at the base........

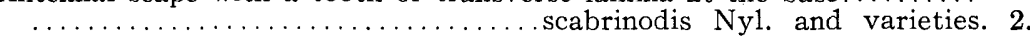
Antennal scape without a tooth or lamina at the base. rubra brevinodis Emery.

2. Color of body pale red; nest built in dry open fields................

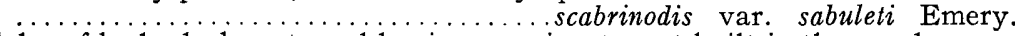
Color of body dark; antennal lamina prominent; nest built in the woods.

..scabrinodis schencki var. emeryana Forel.

\section{M. scabrinodis Nyl.}

A palearctic species with several varieties.

M. scabrinodis var. sabuleti Emery.

This is a pale red variety of the species. It nests in sandy or gravelly sunny places and is often seen in attendance upon aphids.

M. scabrinodis schencki var. emeryana Forel.

A darker form of scabrinodis which nests in the wood. The workers have a very pronounced lobe on the scape.

M. rubra brevinodis Emery.

This species seems to abound in sections where the climate is rather cold and is often collected at high altitudes. It is the host of $L$. emersoni, another ant.

\section{Subfamily DoLICHODERINÆ.}

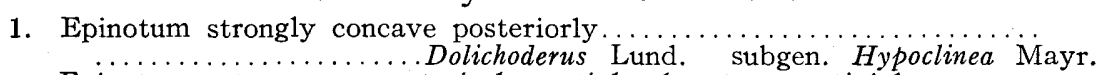
Epinotum not concave posteriorly; petiole absent or vestigial..........

\section{Genus Dolichoderus Lund.}

D. (Hypoclinea) taschenbergi Mayr. var.

Small, rather robust, shining black ants with the posterior portion of their epinotums concave.

This species is an arboreal type and is commonly found attending aphids or scales on trees. When crawling over the trees, they have the habit of moving in files.

\section{Genus Tapinoma Föerster.}

\section{T. sessile Say.}

The workers of this form are slender black ants that nest in the ground or in rotten wood. When nesting in the ground they construct crater-like nests. Although they feed on dead insects, the workers also have a fondness for attending aphids.

* Dr. W. M. Wheeler kindly furnished the key to the species. 


\section{Subfamily PONERINe.}

1. Mandibles long and slender, with coarse bidenticulate teeth...........

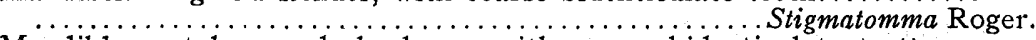
Mandibles not long and slender or with coarse bidenticulate teeth...

Ponera Latr.

Genus Ponera Latr.

P. coarctata pennsylvanica Emery.

The workers of this species are small slender ants with vestigial eyes.

The workers nest under stones in rotten logs, vegetable mold, etc.

\section{Genus Stigmatomma Roger.}

S. pallipes Haldeman.

This species has workers which are slender, dark brown in color, and have the mandibles, antennæ, and legs paler.

The workers are hypogaeic in habits and occur only in rich damp woods under stones, logs, etc. It is not a common species as the form is rather primitive. The colonies are small, being composed of from forty to fifty individuals. 